\title{
ICT Components in MLIS Curriculum in North India: A Content Analysis
}

\author{
Priyanka Chand Bhatt ${ }^{1}$, Paramjeet K. Walia ${ }^{2}$ \\ ${ }^{I}$ (Research Scholar, Department of Library and Information Science, University of Delhi, India) \\ ${ }_{2}^{2}$ (Professor, Department of Library and Information Science, University of Delhi, India)
}

\begin{abstract}
This study analyses the Information and Communication Technology (ICT) course contents of Master's Level Library and Information Science (MLIS) course being conducted in university / departments of north India. The ICT components are identified with the help of University Grants Commission's (India) Model Curriculum report. Universities offering MLIS courses in north India were identified from UGCs complete list of recognized universities. This study is limited to the regular MLIS courses being offered in north India. The skewness in the mentioned objective of ICT components in curriculum is measured using Weighted Average Score. Maximum of the ICT components are offered in theory papers in the selected universities whereas Internet Applications, Website Designing, Multimedia applications, etc. are offered more as practical components. There is a major gap between Theory and Practical approach for the identified ICT components, i.e. more emphasis is given to Theory than Practical.This study gives a content analysis of ICT Components of MLIS curriculum and thus provides the current status of LIS education in north India which adds up to the existing literature of LIS education.
\end{abstract}

Keywords:- LIS education, ICT components, Information and communication technology, Digital library education, MLIS curricula, North India, MLIS, ICT, Curriculum gap

\section{INTRODUCTION}

The objectives of Library and Information Science (LIS) education have been revolutionized with the E-concept. Traditional services are changing towards e-generated library services [1].The library and information scenario is changing at a dynamic pace; there is a paradigm shift from print media to web media; from ownership of documents to access to information; intermediary to end-user model of services; and from location of specific libraries to digital/virtual/hybrid libraries [2]. The developments and innovations in ICT have facilitated changes in the development of curriculum in Library and Information Studies.

"A curriculum of LIS education usually mirrors what is being offered to train librarians and information professionals who will not only acquire the essential knowledge and skills to become qualified personnel in the field but also meet challenges the ever changing information society brings." It is essential to equip the professionals and provide them a state of art eco-system where they can perform according to the need of time and hence the responsibility of departments and curriculum developers is very significant. It is necessary to keep the curriculum flexible to match with the varying dimensions of the discipline. [3]

\section{LIS EDUCATION AND UGC EFFORTS IN INDIA}

After India's independence in 1947, [4] the University Grants Commission (UGC) controls mainly the general course structure of various curricula. The UGC constituted Curriculum Development Committee (CDC) on LIS under the chairmanship of Prof. P.N. Kaula in 1993. The report of this committee was published under the title "Report of the curriculum development committee on Library and Information Science". The publication of this curriculum helped the university departments to update their syllabi as per the requirement in the profession during these periods. Soon after this, many changes occurred in ICT sector, which had a direct impact on the libraries. This made the UGC to undertake a study on the previous report of CDC on LIS. Finally, a modular syllabus was proposed for Indian Universities. This report was published in 2001 under the title "UGC Model Curriculum, Library and Information Science" by Prof. C. R. Karisiddappa being the chairman.

Recommendations of CDC 2001 are quoted as -

In view of the

- Emerging network environment

- Fundamental shift in the goals of the library

- Changes in information storage and delivery mechanisms, 
The education programs should cater the needs of these changed settings by including in their course content, the knowledge and skills required to function effectively in such a view".

The shift from the traditional environment has forced LIS education and training to attempt to improve the quality of programs and hence, LIS curricula need to consolidate ICT concepts, knowledge, skills and proficiency into core competencies, and LIS schools need to provide adequate content and practice that will enable the professionals to use ICTs effectively.

India today stands poised to reap the benefits of a rapidly growing economy and a major demographic advantage that will see the country having the largest source of young people in the world in the next few decades. The challenge and the opportunity are to galvanize our national potential into a dynamic resource: an informed, enlightened and capable young Indian citizenry would not enhance and enrich the process of natural development, but could be a positive force in the world [6].

An analysis of ICT components in LIS Curriculum is relevant in present date to access the utility of the current curriculum. In India, most of the universities follow UGC Model curriculum 2001 for Library and Information Science programs specifically on Master's level. This paper analyses the ICT components in Master's Level LIS Curriculum in northern region of India.

Education system in India is one of the largest and oldest of its own kind. LIS Education in India completed its 100 years in 2011. At present, LIS education in India is offered at different levels, namely:

- Certificate course in Library and Information Science (C.Lib.Sc.)

- Diploma in Library and Information Science

- $\quad$ B.Lib.Sc. /BLIS (Bachelor Degree in Library and Information Science)

- M.Lib.Sc. /MLIS (Master Degree in Library and Information Science)

- MS-LIS(Master of Science in Library and Information Science)

- $\quad$ AIS (Associateship in Information Science)

- $\quad$ PGDLAN (Post Graduate Diploma in Library Automation and Networking)

- M.Phil. (Master of Philosophy) in Library and Information Science

- Ph.D. (Doctor of Philosophy) in Library and Information Science

- D.Litt. in Library and Information Science

According to Geographical Survey of India [7], India has a vast diversity in democracy, climate, culture, language and ethnicity. It is the $7^{\text {th }}$ largest country by area in the world, with a total area of $3,166,414$ square kilometers, and consisting of 29 states and 7 union territories. India is divided into six major regions namely, North, South, East, West, Central and north-east. North India is a loosely defined region consisting of the northern part of India. The term North India officially refers to the seven states and one union territory:

- Chandigarh (Union Territory),

- Delhi,

- Haryana ,

- Himachal Pradesh,

- Jammu \& Kashmir,

- Punjab,

- Uttar Pradesh,

- Uttarakhand

\section{SCOPE AND METHODOLOGY}

The scope of this paper is limited to the regular Library and Information Science post graduate courses, specifically M.L.I.Sc. and equivalent, conducted by LIS Schools of central or state university departments / institutions recognized by University Grants Commission (UGC) in North India.

First step of collecting data for this research involves identification of UGC recognized universities offering M.L.I.Sc. or equivalent program in north India. Institutes were categorized by searching from UGC's list of Central, State and Private Universities. Course contents and other relevant information were hence gathered from the respective websites of the institutions. Some data was gathered through personal visit to university departments also.Universities' details with their respective curriculum/department link is given in the Appendix of this paper.

There are in total 26 institutions at present offering M.L.I.Sc. course, further details are given in following sections. 
Table 1. Universities offering M.L.I.Sc. Course in North India

\begin{tabular}{|c|c|}
\hline Type of University & No. of Institutions \\
\hline Central & 6 \\
\hline State & 15 \\
\hline Private / Deemed & 5 \\
\hline Total & $\mathbf{2 6}$ \\
\hline
\end{tabular}

Departments/schools offering post-graduate course in Library and Information Science (M.L.I.Sc. or equivalent) were recognized from the categorized universities in north India and it was found that in the northern region of India - 6central universities, 15 state universities and 5 Private / Deemed universities are offering at present Master's level Library and Information Science Program as described in Table 1.

For further analysis, this paper limited the scope up to central and state universities recognized by University Grants Commission (UGC) excluding private universities, which leaves total universities to be examined in North India to be 21 ( 6 central and 15 state) out of which data from only 17 universities (5 central and 12 state universities) was collected due to unavailability of the curriculum information both on the website and low response from the departments themselves. State and university category wise distribution of selected sample of 17 universities is categorized in Table 2 as follows.

Table 2. State and category wise distribution of select Universities offering M.L.I.Sc. course in North India

\begin{tabular}{|c|c|c|}
\hline $\begin{array}{c}\text { State/Union } \\
\text { Territory }\end{array}$ & Name of University & $\begin{array}{l}\text { University } \\
\text { Category }\end{array}$ \\
\hline Chandigarh* & Panjab University (PU Chd) & State \\
\hline Delhi & University of Delhi (DU) & Central \\
\hline \multirow{2}{*}{ Haryana } & Kurukshetra University (KUK) & State \\
\hline & MaharshiDayanand University (MDU) & State \\
\hline $\begin{array}{l}\text { Himachal } \\
\text { Pradesh }\end{array}$ & Central University of Himachal Pradesh (CUHP) & Central \\
\hline \multirow[t]{2}{*}{$\begin{array}{ll}\text { Jammu } & \text { \& } \\
\text { Kashmir } & \\
\end{array}$} & University of Jammu (JU) & State \\
\hline & University of Kashmir (UoK) & State \\
\hline \multirow[t]{2}{*}{ Punjab } & Guru Nanak Dev University (GNDU) & State \\
\hline & Punjabi University, Patiala (PU Pat) & State \\
\hline \multirow[t]{8}{*}{ Uttar Pradesh } & Aligarh Muslim University (AMU) & Central \\
\hline & BabasahebBhimraoAmbedkar University (BBAU, LKO) & Central \\
\hline & Banaras Hindu University (BHU) & Central \\
\hline & ChhatrapatiShahujiMaharaj University (CSJMU) & State \\
\hline & Chaudhary Charan Singh University (CCSU) & State \\
\hline & Dr. Ram ManoharLohiaAwadh University (Dr.RMLAU) & State \\
\hline & University of Lucknow (UoL) & State \\
\hline & M.G. KashiVidyapeethVaranasi(M.G.K.V.P.) & State \\
\hline
\end{tabular}

It is also evident from the Table 2 that there isn't any Master's Level Library and Information Science program being offered in the state of Uttarakhand of north region at present.

Table 3. Distribution of select Universities, their Schools and Departments, Year of Establishment of LIS Department, Nomenclature of Master's Level Program, and Duration

\begin{tabular}{|l|l|l|l|l|l|}
\hline $\begin{array}{l}\text { Name of } \\
\text { University }\end{array}$ & School / Faculty & Department & Established & Nomenclature & Duration \\
\hline AMU & $\begin{array}{l}\text { Faculty of Social } \\
\text { Science }\end{array}$ & $\begin{array}{l}\text { Department of Library } \\
\& \text { Information } \\
\text { Science }\end{array}$ & 1950 & M.L.I.Sc. & 1 year \\
\hline $\begin{array}{l}\text { BBAU, } \\
\text { LKO }\end{array}$ & $\begin{array}{l}\text { School of } \\
\text { Information of }\end{array}$ & $\begin{array}{l}\text { Department of Library } \\
\text { and Information }\end{array}$ & 1997 & M.L.I.Sc. & 2 year \\
\hline
\end{tabular}




\begin{tabular}{|c|c|c|c|c|c|}
\hline & $\begin{array}{l}\text { Science } \\
\text { Technology }\end{array}$ & Science & & & \\
\hline $\mathrm{BHU}$ & Faculty of Arts & $\begin{array}{l}\text { Department of Library } \\
\text { and Information } \\
\text { Science }\end{array}$ & 1941 & M.L.I.Sc. & 2 year \\
\hline CUHP & $\begin{array}{l}\text { School of } \\
\text { Mathematics, } \\
\text { Computers and } \\
\text { Information } \\
\text { Science }\end{array}$ & $\begin{array}{l}\text { Department of Library } \\
\text { Science }\end{array}$ & - & M.L.I.Sc. & 2 year \\
\hline $\mathrm{CCSU}$ & Faculty of Arts & \begin{tabular}{ll}
\multicolumn{2}{l}{ Department of Library } \\
$\&$ & Information \\
Science & \\
\end{tabular} & 2004 & M.L.I.Sc. & 1 year \\
\hline CSJMU & - & \begin{tabular}{ll}
\multicolumn{2}{l}{ Department of Library } \\
$\&$ & Information \\
Science & \\
\end{tabular} & 2002 & M.L.I.Sc. & 1 year \\
\hline Dr. RMLAU & - & $\begin{array}{l}\text { Department of Library } \\
\text { Science }\end{array}$ & - & M.Lib.I.Sc. & 1 year \\
\hline GNDU & $\begin{array}{lr}\text { Faculty of Arts } \\
\& & \text { Social } \\
\text { Science } & \\
\end{array}$ & \begin{tabular}{ll}
\multicolumn{2}{l}{ Department of Library } \\
$\& \quad$ Information \\
Science
\end{tabular} & 1970 & $\begin{array}{l}\text { M.L.I.S } \\
\text { (Hons.) }\end{array}$ & 1 year \\
\hline KUK & $\begin{array}{l}\text { Faculty of Arts } \\
\text { \& Languages }\end{array}$ & $\begin{array}{l}\text { Department of Library } \\
\text { and Information } \\
\text { Science }\end{array}$ & 1969 & $\begin{array}{l}\text { M.Lib.\& Inf. } \\
\text { Sc. }\end{array}$ & 1 year \\
\hline M.G.K.V.P. & $\begin{array}{l}\text { Faculty of } \\
\text { Humanities }\end{array}$ & $\begin{array}{l}\text { Department of Library } \\
\text { and Information } \\
\text { Sciences }\end{array}$ & 1987 & M.Lib.I.Sc. & 1 year \\
\hline MDU & $\begin{array}{l}\text { Faculty of Social } \\
\text { Science }\end{array}$ & $\begin{array}{l}\text { Department of Library } \\
\text { and Information } \\
\text { Science }\end{array}$ & - & M.L.I.Sc. & 2 year \\
\hline PU Chd & ( & \begin{tabular}{lr}
\multicolumn{2}{l}{ Department of Library } \\
$\&$ & Information \\
Science & \\
\end{tabular} & 1960 & M.L.I.Sc. & 2 year \\
\hline PU Pat & $\begin{array}{ll}\text { Faculty } & \text { of } \\
\text { Education } & \& \\
\text { Information } & \\
\text { Sciences } & \end{array}$ & \begin{tabular}{ll}
\multicolumn{2}{l}{ Department of Library } \\
$\&$ & Information \\
Science &
\end{tabular} & 1969 & M.Lib.Sc. & 1 year \\
\hline $\mathrm{DU}$ & Faculty of Arts & $\begin{array}{l}\text { Department of Library } \\
\text { and Information } \\
\text { Science }\end{array}$ & 1946 & M.L.I.Sc. & 1 year \\
\hline $\mathrm{JU}$ & - & $\begin{array}{lr}\text { Post } & \text { Graduate } \\
\text { Department of Library } \\
\text { and } \quad \text { Information } \\
\text { Science }\end{array}$ & 1971 & M.L.I.Sc. & 1 year \\
\hline UoK & Faculty of Arts & $\begin{array}{l}\text { Department of Library } \\
\text { and Information } \\
\text { Science }\end{array}$ & 1970 & M.L.I.Sc. & 2 year \\
\hline UoL & Faculty of Arts & \begin{tabular}{ll}
\multicolumn{2}{l}{ Department of Library } \\
$\& \quad$ Information \\
Science
\end{tabular} & 1972 & M.L.I.Sc. & 2 year \\
\hline
\end{tabular}

In north India, most of the departmentshave nomenclature of Master's level course as M.L.I.Sc. whereas some departments have kept the nomenclature as M.Lib. or M.Lib.I.Sc. etc. Department of Library and Information Science, Guru Nanak Dev University, Amritsar, offers M.L.I.Sc. (Hons.) course of 1-year duration consisting of 2 semesters. From the selected sample 10 Departments of Library and Information Science offer 1 year (two semester) Master's Level program of Library and information Science whereas 7 Departments offer 2 year integrated (four semester) Master's Level program of Library and information science. Department of 
Library and Information Science, University of Delhi established in 1946 which is credited for being the first department to offer the Master's Level course in Library and information science.

Another pattern is that the Faculty or Schools in which the Departments of Library and Information Science are established vary in their discipline, i.e., as most of the departments are established under either Faculty of Arts or Faculty of Social Science, but some Departments are categorized under School of Information Science Technology, School of Computer Science and Informatics, School of Mathematics, Computers and Information Science, etc. This pattern shows that where majority universities consider Library Science as a discipline of Social Science/Arts/Humanities, at the same time there are universities which have categorized the Library Science discipline into the Computer Science or Mathematics stream. This obscurity sometimes prevents the entry of more brilliant students into the fold of LIS.

\section{IDENTIFICATION OF ICT COMPONENTS IN MLIS CURRICULA} three categories:

ICT components in Master's level Library and information science curriculum can be categorized into

1. Information Technology: Basics

2. Information Technology: Advanced

3. Applications of ICT in Library and Information Science: Digital Library, Library Automation, Information Retrieval, etc.

UGC Model Curriculum Report, 2001 has described one Module for Information Technology in twoyear Master's Level curriculum of LIS. The report was taken as the reference and further according to current trends, the ICT components have been modified and identifiedas follows:

1. Information Technology

2. Operating Systems and Programming

3. Networking

4. Internet: Basic Features and Tools

5. Database Management System

6. Library Automation

7. Digital Libraries

8. Current Trends in Information Technology

9. Information Storage and Retrieval

10. Computer Applications / MS Office

Further classification of above identified ICT components into sub-components is given in Table 4.

Table 4. Identification of ICT Components w.r.t UGC Model Curricula

\begin{tabular}{|c|c|c|}
\hline S. NO. & Components & Sub-Components \\
\hline \multirow{5}{*}{1} & \multirow{5}{*}{ Fundamentals of ICT } & Definition , Scope and Objectives \\
\hline & & Historical Background of Computers \\
\hline & & Generation of Computer \\
\hline & & Computer Architecture : CPU, I/O Devices, Memory \\
\hline & & Hardware and Software \\
\hline \multirow{6}{*}{2} & \multirow{6}{*}{$\begin{array}{l}\text { Operating Systems \& } \\
\text { Programming }\end{array}$} & MS Windows \\
\hline & & LINUX / UNIX \\
\hline & & Programming Languages \\
\hline & & Algorithms \\
\hline & & Flowcharting \\
\hline & & Search \& Sorting Algorithm, Data Structures \\
\hline \multirow{3}{*}{3} & \multirow{3}{*}{ Networking } & Types of Networks - LAN / MAN / WAN \\
\hline & & Network Protocols - TCP/IP \\
\hline & & Basic Elements of Data Communication system \\
\hline \multirow{2}{*}{4} & \multirow{2}{*}{$\begin{array}{c}\text { Internet : Basic Features } \\
\text { and Tools }\end{array}$} & Connectivity - Dialup, ISDN, Cable Modem, etc. \\
\hline & & E-mail, SMTP, POP3, etc. \\
\hline
\end{tabular}




\begin{tabular}{|c|c|c|}
\hline & & Protocols : Telnet, FTP, HTTP \\
\hline & & Web Browsers \\
\hline & & Web Servers \\
\hline & & Search Engines, Meta Search Engines \\
\hline & & Internet Security - Firewalls and Proxy \\
\hline \multirow{4}{*}{5} & \multirow{4}{*}{$\begin{array}{c}\text { Database Management } \\
\text { Systems }\end{array}$} & $\begin{array}{l}\text { Models - Hierarchical , Network, Relational, Object } \\
\text { Oriented }\end{array}$ \\
\hline & & Software - Oracle, Postgress SQL, MSSQL, CDS/ISIS \\
\hline & & SQL \\
\hline & & Common Interface standard Z39.50 \\
\hline \multirow{8}{*}{6} & \multirow{8}{*}{ Library Automation } & Planning and Implementation \\
\hline & & Automation of In-house operations \\
\hline & & Retro-conversion, Barcoding, RFID \\
\hline & & Bibliographical Databases \\
\hline & & $\begin{array}{l}\text { Library Automation Software : Selection Criteria \& } \\
\text { Evaluation }\end{array}$ \\
\hline & & Case study of Library Automation Software \\
\hline & & Library Networks and Information Systems \\
\hline & & Current Trends (Virtual Library / Hybrid Library, etc.) \\
\hline \multirow{8}{*}{7} & \multirow{8}{*}{ Digital Libraries } & Genesis, Meaning, Need, Importance \\
\hline & & Access Methods \\
\hline & & Digital Library Models \\
\hline & & Open Source Software \\
\hline & & Digital Library Collection Development \\
\hline & & Interoperability Standards \\
\hline & & Retrieval, Interface and Evaluation \\
\hline & & Digital preservation and archiving \\
\hline \multirow{7}{*}{8} & \multirow{7}{*}{ Current Trends } & Web2.0 \\
\hline & & Web 3.0 \\
\hline & & Web OPACs \\
\hline & & Web Directories \\
\hline & & Subject Gateways, Library Portals, etc. \\
\hline & & Blogs, Podcasts, RSS Feeds, IM, Wiki, etc. \\
\hline & & Artificial Intelligences and Expert Systems in Libraries \\
\hline \multirow{5}{*}{9} & \multirow{5}{*}{$\begin{array}{c}\text { Information Storage and } \\
\text { Retrieval }\end{array}$} & Bibliographic description, Bibliographic record formats \\
\hline & & Metadata - Dublin Core, etc. \\
\hline & & Online Search Strategies \\
\hline & & Content Creation - HTML/XML , \\
\hline & & Bib record formats - MARC, CCF, etc. \\
\hline 10 & Computer Applications & MS OFFICE \\
\hline
\end{tabular}

Further sections give a detailed analysis of the ICT components and sub-components being identified in Table 4 and their inclusion and implementation in the selected sample of North Indian Universities' Departments of Library and Information Science.

\section{ICT COMPONENTS IN MASTER'S LEVEL LIS CURRICULA}

As described in the previous sections, a sample size of 17 universities was taken. ICT components were identified and were further categorized into sub-components. For each sub-component the number of LIS 
Departments that have included that particular sub-component into their curricula both in theory as well as practical, is determined. Finally, for each ICT component, an average of LIS schools (or departments) is calculated, for Theory and Practical content, from the sub-components of ICT. Table 5 shows the findings.

\section{Table 5: Average (\%) of select LIS schools, in north India,including identified ICT components in Theory and Practical content $(n=17)$}

\begin{tabular}{|l|c|c|}
\hline \multicolumn{1}{|c|}{ ICT Components } & $\begin{array}{c}\text { Theory } \\
(\boldsymbol{\%})\end{array}$ & $\begin{array}{c}\text { Practical } \\
(\boldsymbol{\%})\end{array}$ \\
\hline Fundamentals of ICT & $51 \%$ & $6 \%$ \\
\hline Operating systems \& Programming & $28 \%$ & $9 \%$ \\
\hline Networking & $75 \%$ & $8 \%$ \\
\hline Internet : Basic Features and Tools & $61 \%$ & $24 \%$ \\
\hline Database Management Systems & $31 \%$ & $3 \%$ \\
\hline Library Automation & $58 \%$ & $26 \%$ \\
\hline Digital Libraries & $40 \%$ & $34 \%$ \\
\hline Current Trends & $49 \%$ & $18 \%$ \\
\hline Information Storage and Retrieval & $64 \%$ & $28 \%$ \\
\hline Computer Applications & $24 \%$ & $35 \%$ \\
\hline
\end{tabular}

Table 5 can be easily understood with the pictorial representation in Figure 1 as follows:

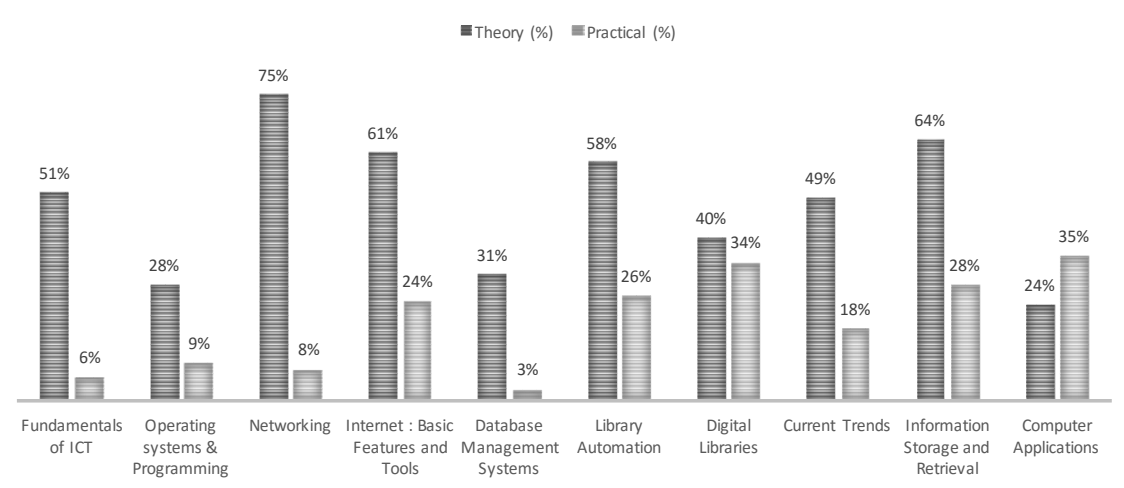

Figure 1: Average (\%) of select LIS schools, in north India, including identified ICT components in Theory and Practical content $(n=17)$

Theory $(\%)$ indicates the percentage of select LIS schools (departments) out of the sample size (i.e., $\mathrm{n}=$ 17) offering respective ICT component in theory content, similarly, Practical(\%) indicates the percentage of LIS Schools (or departments) offering respective ICT component in Practical content.

It can be observed that "Networking" is included in maximum $75 \%$ of select LIS schools as Theory content whereas in Practical content "Digital Libraries" is included in 34\% of select LIS Schools. There is a visible imbalance between Theory and Practical content in the course curricula of Master's Level LIS program in select LIS schools in North India. And only less than $50 \%$ of the selected sample has practical content of identified ICT components.

Further, university wise detailed analysis of both Theory and Practical ICT components, semester (or year) wise has been conducted. To get the relative understanding of what is actual scenario based on the curriculum content analyzed by this paper, a Weighted average score is calculated, on the basis of analyzed Theory and Practical weightage of ICT components of each M.L.I.Sc. program from selected LIS Schools.

Weighted Average Score - Analyzed $\left(\mathbf{W}_{\mathbf{a}}\right)$ for both Theory(Th) and Practical(Pr) is calculated as follows :

$$
\mathbf{W}_{\mathbf{a}}(\mathrm{Th})=\sum \frac{T h(i)}{\text { Total Score }} \text {, and } \mathbf{W}_{\mathbf{a}}(\operatorname{Pr})=\sum \frac{\operatorname{Pr}(i)}{\text { Total Score }}
$$

Where, i denotes the number of semester, i.e., $i=1,2,3,4$. (since maximum semester are 4) 
The above formula is nothing but the summation of number of Theory components per semester divided by the Total Score and similarly for the Practical components.

Following Table 6 gives detailed analysis of Theory and Practical components being taught in each semester of selected departments of universities offering M.L.I.Sc. course in north India. Total score is calculated on the basis of total Theory and Practical ICT components in the curriculum which are exhaustively analyzed as mentioned in above sections. Based on the number of theory and practical components and the Total Score and $\mathbf{W}_{\mathbf{a}}$ for each selected university as described above.

Table 6. Detailed analysis of Theory (Th) and Practical (Pr) components of ICT in MLIS curriculum semester wise and Weighted Average Score (\%) for Theory and Practical content.

\begin{tabular}{|c|c|c|c|c|c|c|c|c|c|c|c|}
\hline \multirow[t]{2}{*}{ Semester } & \multicolumn{2}{|l|}{ I } & \multicolumn{2}{|l|}{ II } & \multicolumn{2}{|l|}{ III } & \multicolumn{2}{|l|}{ IV } & \multirow{2}{*}{$\begin{array}{l}\text { Total } \\
\text { Score }\end{array}$} & \multicolumn{2}{|c|}{$\mathrm{W}_{\mathrm{a}}(\%)$} \\
\hline & Th & $\mathbf{P r}$ & Th & $\mathbf{P r}$ & Th & Pr & Th & Pr & & Th & Pr \\
\hline \multicolumn{12}{|c|}{ Name of university } \\
\hline AMU & 12 & 6 & 20 & 5 & - & - & - & - & 43 & 74 & 26 \\
\hline BBAU, LKO & 15 & 15 & 0 & 0 & 13 & 13 & 18 & 18 & 92 & 50 & 50 \\
\hline BHU & 18 & 0 & 4 & 2 & 11 & 0 & 0 & 6 & 41 & 80 & 20 \\
\hline CUHP & 24 & 0 & 21 & 0 & 14 & 8 & 0 & 5 & 72 & 82 & 18 \\
\hline CCSU* & 22 & 8 & - & - & - & - & - & - & 30 & 73 & 27 \\
\hline CSJMU* & 25 & 9 & - & - & - & - & - & - & 34 & 74 & 26 \\
\hline Dr.RMLAU & 5 & 4 & 15 & 0 & - & - & - & - & 24 & 83 & 17 \\
\hline GNDU & 0 & 0 & 28 & 12 & - & - & - & - & 40 & 70 & 30 \\
\hline KUK & 15 & 4 & 13 & 7 & - & - & - & - & 39 & 72 & 28 \\
\hline M.G.K.V.P & 0 & 0 & 22 & 7 & - & - & - & - & 29 & 76 & 24 \\
\hline $\mathrm{MDU}$ & 19 & 0 & 4 & 5 & 20 & 0 & 0 & 11 & 59 & 73 & 27 \\
\hline PU Chd & 19 & 0 & 0 & 0 & 23 & 21 & 0 & 0 & 63 & 67 & 33 \\
\hline $\mathrm{PU} \mathrm{Pat}^{+}$ & 20 & 0 & - & - & - & - & - & - & 20 & 100 & 0 \\
\hline DU & 17 & 1 & 5 & 13 & - & - & - & - & 36 & 61 & 39 \\
\hline $\mathrm{JU}^{*+}$ & 12 & 0 & - & - & - & - & - & - & 12 & 100 & 0 \\
\hline UoK & 17 & 0 & 7 & 0 & 6 & 5 & 7 & 12 & 54 & 69 & 31 \\
\hline UoL & 22 & 0 & 0 & 7 & - & - & - & - & 29 & 76 & 24 \\
\hline
\end{tabular}

(* Annual programs (not semester wise), ${ }^{+}$No practical for ICT components)

The above table can be understood as follows: For Aligarh Muslim University (AMU), total 12 identified ICT sub-components are included in Theory content of First Semester and 6 ICT sub-components in Practical content of First Semester. Further, in Second Semester, total 20 ICT sub-components are included in Theory whereas 5 ICT sub-components in Practical content. Since, AMU has 1 year MLIS course, hence third and fourth semester are left blank. Total Score is calculated as the sum of all respective numbers. Then $\mathbf{W}_{\mathbf{a}}(\mathrm{Th})$ $=(12+20) / 43$ and $\mathbf{W}_{\mathbf{a}}(\operatorname{Pr})=(6+5) / 43 . \mathbf{W}_{\mathbf{a}}(\mathrm{Th}) \%$ of AMU is 74 which means $74 \%$ of the identified ICT components are included in MLIS Theory course content of the university and $26 \%$ in Practical content.

Figure 2illustrates a pictorial distribution of Total Theory and Practical components of ICT in the curriculum of selected LIS departments of universities. The ratio between Theory and Practical Components is still uneven where Theory is way more than Practical Components. Punjabi University Patiala and Jammu University do not have Practical Components in the M.L.I.Sc. curriculum. And the highest practical components are being included in BBAU Lucknow followed by Panjab University, Chandigarh.

Figure 3shows the Trend of Weighted Average Score, calculated in Table 6, for the Theory and Practical ICT components in the selected universities. In the graph the Intersection point of Value 50 may also be considered as the Balanced Point, i.e., at this point the Theory and Practical Components are equally distributed in the curricula. In the selected universities such scenario is only seen in one university, i.e. BBAU Lucknow. This analysis shows that even though much emphasis has been given to the inclusion of ICT 
components in the curricula, but we are still lagging in the practical aspects of the same and which questions the skills of the fresh outcomes from the universities.

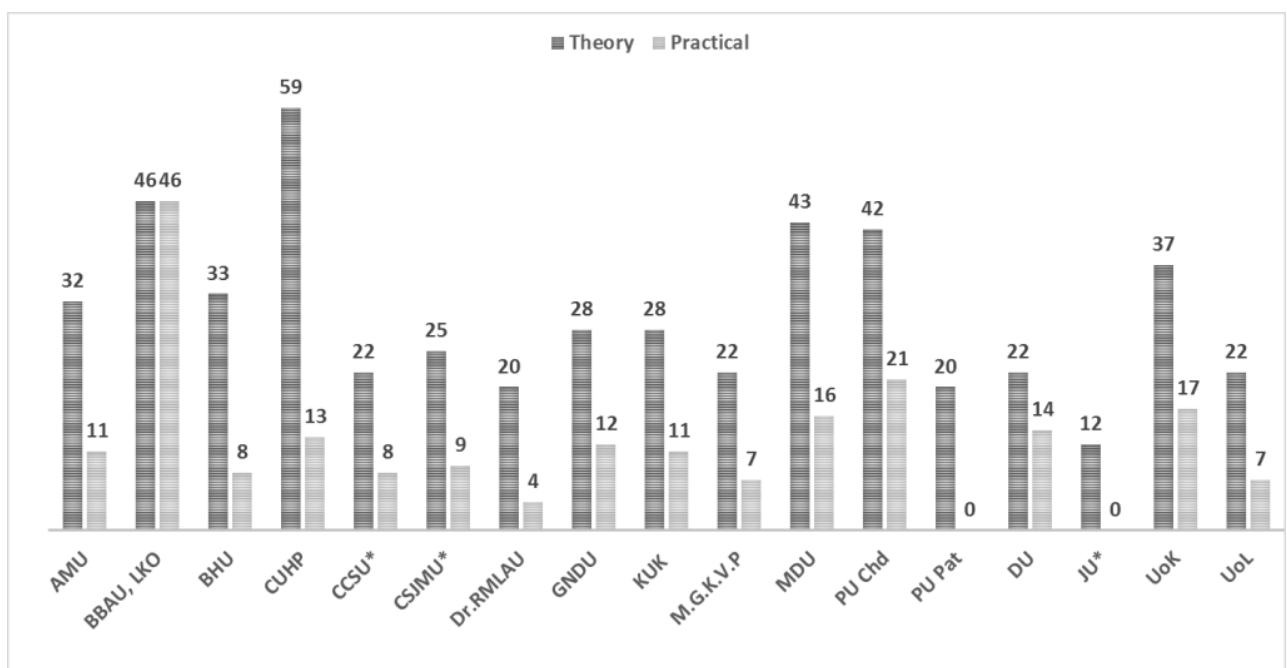

Figure2. Distribution of Total Theory and Practical ICT components in the curricula of selected universities

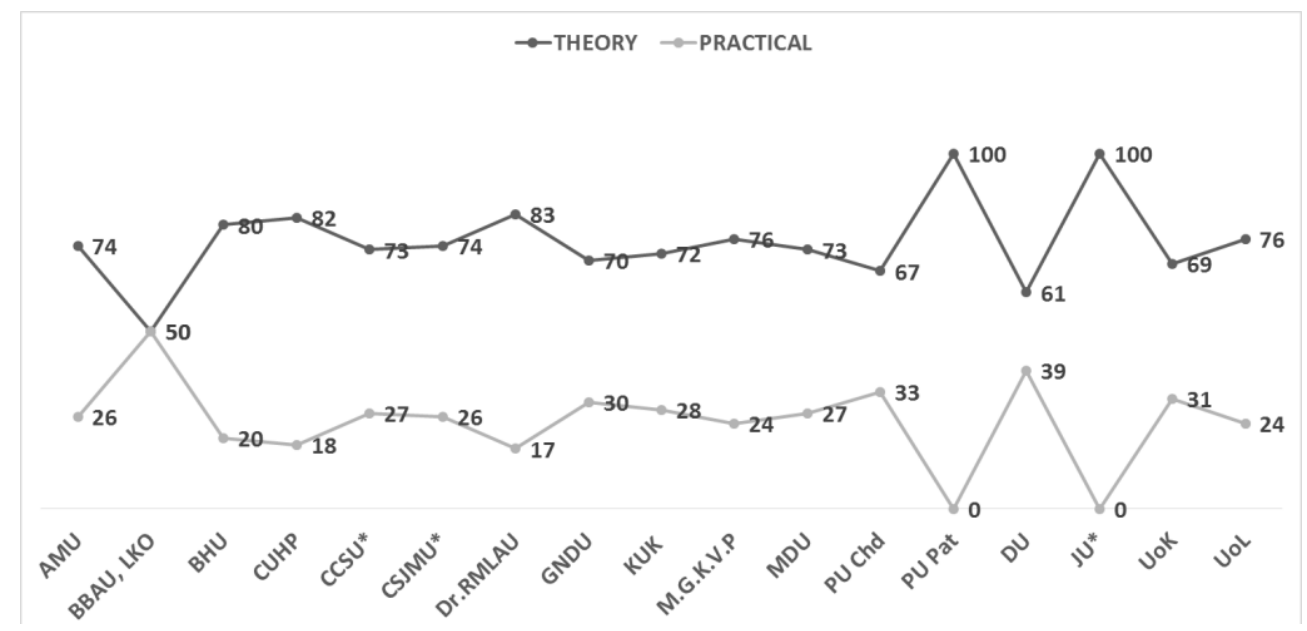

Figure 3. Weighted Average Score (\%)

\section{OBSERVATIONS AND LIMITATIONS}

- Most of the universities have adopted the UGC Model Curriculum 2001 model for the curriculum development of Library and Information Science curricula, but still there are 1-year Master's in Library and Information Science Programs being offered instead of 2 year programs. In north India, as analyzed by this paper, approx. 59\% universities offer 1-year Master's level program in Library and Information Science whereas $41 \%$ offer 2 year programs for the same. One-year duration programs do not offer sufficient components for the advanced training of the learners and thus not providing enough hands on experience for the graduating professionals who will be entering the job market.

- A major observation is that not even a single ICT component is uniformly added to curriculum amongst the curriculum of all the listed 17 universities. Maximum of 15 universities is recorded to have same or similar kind of ICT components in the curriculum.

- Even if we analyze the ICT components of every curriculum being offered in the select universities of North India, and even if every latest/current ICT component is being included in the curriculum, it doesn't make much difference until there isn't hands-on enough practical experience for the same.

- Though Library and Information Science as a course is now being considered among the professionals as being equivalent to the Computer Science course, but it is very important to determine that 
which components are supposed to be emphasized from the core Computer Science discipline and which components should be molded according to their application in the Library and Information Science Profession. For example, the Programming Languages component of ICT which is being included in the Library and Information Science Curriculum, what utility does it have in the actual professional path of a Library and Information Science graduate? Though Programming Languages is included as theory in only 6 universities and as practical in 4 universities from the select universities offering post graduate M.L.I.Sc. Program in north India.

- A major problem that is being faced by many universities in the region that act as barriers and are confronting the use of ICT in the training and education of LIS in India:

- Lack of infrastructure facilities available at the disposal of LIS departments

- Lack of ICT access to LIS learners and teachers

- Lack of financial resources to adopt the latest innovative means

- Lack of proper perspective and policy development by the top management of LIS institutions

- Lack of perception on the part of LIS learners

- Lack of well-connected telecommunication facilities to explore and exploit the latest innovations in the information delivery and consumption

- Lack of interest on the part of faculty (in most cases) due to obvious reasons

\section{CONCLUSION}

- It can be concluded that LIS education in India is in the mainstream of ICT exploitation and consumption, even if there is slight resistance. Market demand of ICT skilled LIS graduates and broad perspective of information management has expanded. Thus role of ICT will always keep increasing.In current age, more graduates are coming from versatile backgrounds (applied courses) and they have computer knowledge embedded in their primary education, thus universities need to focus more on the practical sessions and hands on experience for the students to handle the technicalities and difficulties associated with the profession and to deal with the day to day problems in the operations and functions of the Library and information centers. There is a requirement to design the skill centered curriculum to ensure the methods to imbibe these skills to professionals.

- It is important to understand the meaning of Information and Communication Technology (ICT) in context of Library and Information Science. Whether how much of computer science core components should be included in the curriculum is a debating topic since decades. LIS education in India is being pushed ahead of the actualities by implementing computer applications and other areas of information technology.

- A balance between theory and practice can be considered the best approach because it enables the curriculum to respond to the need for extensive knowledge in information systems and technology, while at the same time addressing market needs for practical skills [8].

- $\quad$ ICT components offered in MLIS curricula should be aligned towards their application in Library and Information Science in a structured way and less emphasis should be given to the core form of advanced information technology components in particular.

- Though it is observed that Information Technology has influenced the Library and Information Profession the most and the new personnel entering the profession should be proficient with the latest technology and in-house operations of the field, but the curriculum should be a heterogeneous mixture of both traditional and ICT components and not aligned more towards ICT components in particular.

- Most important point to understand is that referring to current context and technological infrastructure of India, every field of work needs to be equipped with technical ICT driven tools and methods. Majority of the LIS professionals in India come from the background which does not give them the kind of exposure which they require to deploy in their professional activities.

- The medium of teaching plays a vital role in imbibing these soft skills in existing and potential work force in the field of Library and Information Science. This study proclaims the need to emphasize equal weightage to medium of teaching (theory as well as practical) rather than only designing curriculum and its relevance with the need of professional skills.

- LIS schools in India must harness the opportunities offered by ICTs in teaching and learning, for market-driven curricula, acquiring of relevant, up-to-date educational technologies and resources, and the use/application of state-of-the-art educational methods and techniques.[9]It is important that LIS schools 
continue to increase the use of achieving greater effectiveness, especially since the field of LIS has become essentially ICT-oriented.

\section{REFERENCES}

[1] P. K. Jain, H. Kaur, \&, P. Babbar. LIS Education in India: Challenges for Students and Professionals in the Digital Age. In A. Abdullah (Ed.), ICOLIS2007, (pp. 481-488). FCSIT.

[2] B. Ramesh Babu. Trends, Challenges and Future of Library and Information Science Education in India. DESIDOC Bulletin of Information Technology, 27(5), 2007, 17-26.

[3] H. Chu. Curricula of LIS programs in the USA: a content analysis In C. Khoo, D. Singh \& A.S. Chaudhry (Eds.), Proc. Asia-Pacific Conference on Library \& Information Education \& Practice 2006, Singapore, 2006, 328-337.

[4] Univeristy Grants Commission. http://www.ugc.ac.in/

[5] University Grants Commission. UGC Model curriculum: Library and Information Science. New Delhi: UGC. 2001

[6] P. K. Walia. Library and Information Science Education in North India LIS education in north India, trends and issues of LIS in north India. Inf. Technol. DESIDOC Journal of Library \& Information Technology, 30(5), 2010, 9-18.

[7] "Northern Region - Geological Survey of India". Geological Survey of India, MOI, Government of India. Retrieved 2 May 2015.

[8] D. Rosenberg. An Overview of education for librarianship in Anglophone sub-Saharan Africa. In Wise, M. (editor), 2000. Education for Librarianship and Information Science in Africa. Denver: International Academic Publishers, 2000, 11-33.

[9] Mabel K. Minishi-Majanja. Integration of ICTs in Library and Information Science Education in subSaharan Africa in World Library and Information Congress: 73rd IFLA General Conference and Council. 2007

\section{APPENDIX}

\begin{tabular}{|c|c|c|}
\hline $\begin{array}{l}\text { Name of } \\
\text { University }\end{array}$ & Department & Website link \\
\hline $\begin{array}{l}\text { Aligarh Muslim } \\
\text { University }\end{array}$ & $\begin{array}{l}\text { Dept. of Library \& } \\
\text { Information Science }\end{array}$ & $\begin{array}{c}\text { http://www.amu.ac.in/departme } \\
\text { ntpage.jsp?did=80 }\end{array}$ \\
\hline $\begin{array}{l}\text { BabasahebBhimrao } \\
\text { Ambedkar } \\
\text { University, } \\
\text { Lucknow }\end{array}$ & $\begin{array}{l}\text { Department of Library } \\
\text { and Information } \\
\text { Science }\end{array}$ & $\begin{array}{l}\text { http://www.bbau.ac.in/SIST/DL } \\
\text { IS/Dept_Library.aspx }\end{array}$ \\
\hline $\begin{array}{l}\text { Banaras Hindu } \\
\text { University }\end{array}$ & $\begin{array}{l}\text { Department of Library } \\
\text { and Information } \\
\text { Science }\end{array}$ & $\begin{array}{l}\text { http://www.bhu.ac.in/arts/lis/ind } \\
\text { ex.html }\end{array}$ \\
\hline $\begin{array}{c}\text { Central University } \\
\text { of Himachal } \\
\text { Pradesh }\end{array}$ & $\begin{array}{l}\text { Department of Library } \\
\text { Science }\end{array}$ & $\begin{array}{l}\text { http://www.cuhimachal.ac.in/lib } \\
\text { rary_science_mcis.aspx }\end{array}$ \\
\hline $\begin{array}{c}\text { Chaudhary Charan } \\
\text { Singh University, } \\
\text { Meerut }\end{array}$ & $\begin{array}{l}\text { Department of Library } \\
\text { \& Information Science }\end{array}$ & $\begin{array}{c}\text { http://www.ccsuniversity.ac.in/n } \\
\text { ew/Department-Library-Info- } \\
\text { Sc.htm }\end{array}$ \\
\hline $\begin{array}{l}\text { ChhatrapatiShahuji } \\
\text { Maharaj } \\
\text { University, Kanpur }\end{array}$ & $\begin{array}{l}\text { Department of Library } \\
\text { \& Information Science }\end{array}$ & $\begin{array}{l}\text { http://www.kanpuruniversity.or } \\
\text { g/library_information_science.h } \\
\text { tm }\end{array}$ \\
\hline $\begin{array}{c}\text { Dr. Ram } \\
\text { ManoharLohiaAwa } \\
\text { dh University }\end{array}$ & $\begin{array}{l}\text { Department of Library } \\
\text { Science }\end{array}$ & $\begin{array}{c}\text { http://www.rmlau.ac.in/lib_sc.as } \\
\text { px }\end{array}$ \\
\hline $\begin{array}{l}\text { Guru Nanak Dev } \\
\text { University }\end{array}$ & $\begin{array}{l}\text { Department of Library } \\
\& \text { Information Science }\end{array}$ & Searching Mechanisms \\
\hline
\end{tabular}




\begin{tabular}{|c|c|c|}
\hline $\begin{array}{l}\text { Kurukshetra } \\
\text { University }\end{array}$ & $\begin{array}{l}\text { Department of Library } \\
\text { and Information } \\
\text { Science }\end{array}$ & $\begin{array}{l}\text { http://www.kuk.ac.in/informatio } \\
\text { n.php?action=showContent } \& \text { L0 } \\
\text { 1_id=OA==\&L01_direction=H } \\
\text { \&L03_id=Mzk=\&L02_id=MjE } \\
=\& \text { sublevel=y }\end{array}$ \\
\hline $\begin{array}{c}\text { M.G. } \\
\text { KashiVidyapeeth, } \\
\text { Varanasi }\end{array}$ & $\begin{array}{l}\text { Department of Library } \\
\text { and Information } \\
\text { Sciences }\end{array}$ & $\begin{array}{c}\text { http://mgkvp.ac.in/pgsyllabin/m } \\
\text { libs4715.pdf }\end{array}$ \\
\hline $\begin{array}{l}\text { MaharshiDayanand } \\
\text { University, Rohtak }\end{array}$ & $\begin{array}{l}\text { Department of Library } \\
\text { and Information } \\
\text { Science }\end{array}$ & $\begin{array}{c}\text { http://www.mdurohtak.ac.in/inf } \\
\text { o/acad_fac_socscie_libraryinfor } \\
\text { mscience.html }\end{array}$ \\
\hline Panjab University & $\begin{array}{l}\text { Department of Library } \\
\text { \& Information Science }\end{array}$ & http://libraryscience.puchd.ac.in \\
\hline $\begin{array}{l}\text { Punjabi University, } \\
\text { Patiala }\end{array}$ & $\begin{array}{l}\text { Department of Library } \\
\text { \& Information Science }\end{array}$ & $\begin{array}{c}\text { http://punjabiuniversity.ac.in/pbi } \\
\text { uniweb/pages/departments/newl } \\
\text { ibrary.html\#coursesoffered }\end{array}$ \\
\hline University of Delhi & Department of LIS & ww.dlis.du.ac.in \\
\hline $\begin{array}{l}\text { University of } \\
\text { Jammu }\end{array}$ & $\begin{array}{l}\text { Post Graduate } \\
\text { Department of Library } \\
\text { and Information } \\
\text { Science }\end{array}$ & $\begin{array}{c}\text { http://www.jammuuniversity.in/ } \\
\text { departments/lib\%20science/prog } \\
\text { ram.asp }\end{array}$ \\
\hline $\begin{array}{l}\text { University of } \\
\text { Kashmir }\end{array}$ & $\begin{array}{c}\text { Department of Library } \\
\text { and Information } \\
\text { Science }\end{array}$ & $\begin{array}{l}\text { http://lis.uok.edu.in/Coursesoffe } \\
\text { red.aspx }\end{array}$ \\
\hline $\begin{array}{l}\text { University of } \\
\text { Lucknow }\end{array}$ & $\begin{array}{l}\text { Department of Library } \\
\text { \& Information Science }\end{array}$ & $\begin{array}{l}\text { http://www.lkouniv.ac.in/arts_li } \\
\text { bais.html\#Courses-tab }\end{array}$ \\
\hline
\end{tabular}

